\title{
PENYULUHAN TENTANG BAHAYA SEKS BEBAS PADA REMAJA DIDESA RAMA MURTI III SEPUTIH RAMAN LAMPUNG TENGAH
}

\author{
Neneng Siti Lathifah ${ }^{1}$, Nurul Isnaini ${ }^{2}$ \\ ${ }^{1}$ email nenengmalahayati@gmail.com \\ ²email isnaininurul50@yahoo.co.id
}

\begin{abstract}
ABSTRAK
Kesehatan Reproduksi Muda Mudi (KERMUDI) yang artinya mengajak remaja untuk mengetahui tentang bahaya sex bebas dengan berbagai implikasi dan dampak negatifnya merupakan suatu masalah global yang mengancam kehidupan masyarakat, bangsa dan negara. Berdasarkan permasalahan tersebut penyuluhan pendidikan kesehatan di kalangan remaja perlu dilakukan agar remaja dapat lebih mengerti dan memiliki daya tangkal terhadap pengaruh negatif. Metode ceramah, diskusi, dan tanya jawab dipilih untuk menjelaskan mengenai karakteristik dan perkembangan motorik remaja di desa rama murti III. Dengan memperhatikan persentase kehadiran dan keaktifan peserta dalam setiap sesi tanya jawab dapat disimpulkan bahwa peserta mampu mengenali dampak perilaku seks bebas di kalangan remaja. Harapannya mereka mampu secara mandiri menjauhi dan menghindari hal tersebut. Rekomendasi kegiatan ini adalah perlunya penyuluhan dilaksanakan secara berkala, terprogram, dan berkesinambungan, khususnya sehingga kesadaran dan daya tangkal remaja terhadap perilaku seks bebas dapat lebih ditingkatkan.
\end{abstract}

Kata Kunci : Seks Bebas, Remaja

\section{ABSTRACT}

Youth Reproductive Health (KERMUDI) which means inviting adolescents to know about the dangers of free sex with its various implications and negative impacts is a global problem that threatens the life of society, nation and state. Based on these problems, health education education among adolescents needs to be done so that adolescents can better understand and have the power to resist negative influences. The lecture, discussion and question and answer methods were chosen to explain the characteristics and motoric development of adolescents in the village of Rama Murti 3. By paying attention to the percentage of attendance and activeness of the participants in each question and answer session, it can be concluded that the participants are able to recognize the impact of free sex behavior among adolescents. The hope is that they will be able to independently stay away from and avoid this. The recommendation of this activity is the need for counseling to be carried out periodically, programmed, and continuously, especially so that awareness and deterrence of adolescents towards free sex behavior can be increased.

Keywords: Free Sex, Teenagers

\section{PENDAHULUAN}

Angka kematian ibu dan bayi saat ini masih sangat tinggi. Hal tersebut disebabkan oleh berbagai factor, salah satu diantaranya adalah kurangnya 
pengetahuan masyarakat tentang kesehatan reproduksi. Aborsi adalah penyumbang angka kematian ibu dan bayi yang cukup besar. (Ratna,2021). Pelaku aborsi ternyata bukan saja wanita yang sudah menikah tetapi tidak menginginkan anak, melainkan wanita yang belum menikah pun banyak yang melakukannya. Bahkan yang sangat memprihatinkan, hampir sebagian besar wanita yang melakukan aborsi adalah berasal dari kalangan remaja yangmasih duduk di bangku sekolah atau kuliah.

Perilaku remaja yang demikian disebabkan karena beberapa factor. Kurangnya pendidikan tentang kesehatan reproduksi dan bahaya free sex merupakan factor pemicu terbesar. Semakin canggihnya tekhnologi juga banyak disalahgunakan sebagai media untuk memicu terjadinya sex bebas di kalangan remaja.(Jalilah,2021). Sebagai praktisi kesehatan khususnya sebagai bidan yang juga bertanggung jawab terhadap kesehatan reproduksi remaja, maka seharusnya kita ikut menekan angka sex bebas pada remaja. Melalui penyuluhan-penyuluhan yang dutujukan kepada remaja, diharapkan mereka dapat semakin mengerti dan memahami bahwa free sex hanya akan membawa akibat negative bagi diri mereka. Dengan demikian diharapkan angka aborsi akan mengalami penurunan dan angka kematian ibu dan bayipun akan menurun.

\section{MASALAH}

Alasan kami memilih tempat kegiatan karena di Desa Rama Murti III Seputih Raman Lampung Tengah adalah tempat kegiatan penyuluhan dimana didaptkan hasil bahwa banyak remaja yang tidak banyak mengetahui pendidikan kesehatan tentang bahaya seks bebas



\section{METODE}

i. Tujuan Persiapan

Tahap persiapan dari kegiatan adalah pre planning, persiapanpenyajian dengan lcd, ppt.

ii. Tahap Pelaksanaan tanggal 27Maret $2021 \mathrm{Jam} 10.00 \mathrm{Wib}$

iii. Acara ini dengan pemberitahuan kepada Kepala Kampung, Kepala Desa Dusun V dan Dusun VI untuk meminta izin mengadakan penyuluhan tentang bahaya seks bebas pada remaja di desa rama murti III sebanyak 
30 orang.

\section{HASIL DAN PEMBAHASAN}

Metode pelaksanaan dalam kegiatan penyuluhan pendidikan kesehatan tentang bahaya seks bebas dilaksanakan pada tanggal 27 Maret 2021 di Kantor Balai Desa.Pelaksanaan penyuluhan ditujukan pada remaja di desa rama murti III.Metode yang digunakan adalah ceramah,tanyan jawab atau evaluasi. Materi yang telah diberikan cukup dipahami terbukti adanya peningkatan pengetahuan peserta menjawab pertanyaan yg benar.

\section{A. Pengertian remaja dan reproduksi}

Remaja didefinisikan sebagai masa peralihan dari masa kanak-kanak ke masa dewasa.Batasan usia remaja berbeda-beda sesuai dengan sosial budaya setempat.Menurut WHO (badan PBB untuk kesehatan dunia) batasan usia remaja adalah 12 sampai 24 tahun.(Ayu,2019).Sedangkan dari segi program pelayanan, definisi remaja yang digunakan oleh Departemen Kesehatan adalah mereka yang berusia 10 sampai 19 tahun dan belum kawin.Sementara itu, menurut BKKBN (Direktorat Remaja dan Perlindungan Hak Reproduksi) batasan usia remaja adalah 10 sampai 21 tahun. Istilah reproduksi berasal dari kata re yangartinya kembali dan kata produksl yang artinya membuat atau menghasilkan.Jadi istilah reproduksi mempunyai arti suatu proses kehidupan manusia dalam menghasilkan keturunan demi kelestarian hidupnya.Sedangkan yang disebut organ reproduksi adalah alat tubuh yang berfungsi untuk reproduksi manusia.

\section{B. Pengertian free sex}

Seks bebas adalah hubungan seksual yang dilakukan diluar ikatan pernikahan, baik suka sama suka atau dalam dunia prostitusi. Seks bebas bukan hanya dilakukan oleh kaum remaja bahkan yang telah berumah tangga pun sering melakukannya dengan orang yang bukan pasangannya.(Atfa,2019). Biasanya dilakukan dengan alasan mencari variasi seks ataupunsensasi seks untuk mengatasi kejenuhan.

Seks bebas sangat tidak layak dilakukan mengingat resiko yang sangat besar. Pada remaja biasanya akan mengalami kehamilan diluar nikah yang memicu terjadinya aborsi. Ingat aborsi itu sangatlah berbahaya dan beresiko kemandulan bahkan kematian. Selain itu tentu saja para pelaku seks bebas sangat beresiko terinfeksi virus HIV yang menyebabkan AIDS, ataupun penyakit menular seksual lainnya.

Pada orang yang telah menikah, seks bebas dilakukan karena mereka mungkin hanya sekedar having fun. Biasanya mereka melakukan perselingkuhan denga orang lain yang bukan pasangan resminya, bahkan ada juga pasangan suami istri yang mencari orang ketiga sebagai variasi seks mereka. Ada juga yang bertukar pasangan. Semua kelakuan diatas dapat dikategorikan seks bebas dan para pelakunya sangat berisiko terinfeksi virus HIV. 


\section{Remaja dan free sex}

Sudah menjadi maklum, remaja memang sosok yang sangat menarik untuk diperbincangkan. Kenapa?. Remaja masa pencarian jati diri yang mendorongnya mempunyai rasa keingintahuan yang tinggi, ingin tampil menonjol, dan diakui eksistensinya. Namun disisi lain remaja mengalami ketidakstabilan emosi sehingga mudah dipengaruhi teman dan mengutamakan solidaritas kelompok. Diusia remaja, akibat pengaruh hormonal, jugamengalami perubahan fisik yang cepat dan mendadak.

Perubahan ini ditunjukkan dari perkembangan organ seksual menuju kesempurnaan fungsi serta tumbuhnya organ genetalia sekunder. Hal ini menjadikan remaja sangat dekat dengan permasalahan seputar seksual. Namun terbatasnya bekal yang dimiliki menjadikan remaja memang masih memerlukan perhatian dan pengarahan.

Ketidakpekaan orang tua dan pendidik terhadap kondisi remaja menyebabkan remaja sering terjatuh pada kegiatan tuna sosial. Ditambah lagi keengganan dan kecanggungan remaja untuk bertanya pada orang yang tepat semakin menguatkan alasan kenapa remaja sering bersikap tidak tepat terhadap organ reproduksinya. Data menunjukkan dari remaja usia 12-18 tahun, 16\% mendapat informasi seputar seks dari teman, $35 \%$ dari film porno, dan hanya $5 \%$ dari orang tua.

D. Dampak Seks Bebas terhadap Kesehatan Fisik dan Psikologis Remaja

1. Dampak fisiologis

a. Aborsi

Pengetahuan remaja mengenai dampak seks bebas masih sangat rendah. Yang paling menonjol dari kegiatan seks bebas ini adalah meningkatnya angka kehamilan yang tidak diinginkan. Setiap tahun ada sekitar 2,3 juta kasus aborsi di Indonesia dimana 20 persennya dilakukan remaja.(Utami,2020). Di Amerika, 1 dari 2 pernikahan berujung pada perceraian, 1 dari 2 anak hasil perzinahan, $75 \%$ gadis mengandung di luar nikah, setiap hari terjadi 1,5 juta hubungan seks dengan pelacuran. Di Inggris 3 dari 4 anak hasil perzinahan, 1 dari 3 kehamilan berakhir dengan aborsi, dan sejak tahun 1996 penyakitsyphillis meningkat hingga 486\%. Di Perancis, penyakit gonorhoe meningkat $170 \%$ dalam jangka waktu satu tahun. Di negara liberal, pelacuran, homoseksual/ lesbian, incest, orgy, bistiability, merupakan hal yang lumrah bahkan menjadi industri yang menghasilkan keuntungan ratusan juta US dolar dan disyahkan oleh undangundang. Lebih dari 200 wanita mati setiap hari disebabkan komplikasi pengguguran (aborsi) bayi secara tidak aman. Meskipun tindakan aborsi dilakukan oleh tenaga ahlipun masih menyisakan dampak yang membahayakan terhadap keselamatan jiwa ibu. Apalagi jika dilakukan oleh tenaga tidak profesional (unsafe abortion).

Secara fisik tindakan aborsi ini memberikan dampak jangka pendek secara langsung berupa perdarahan, infeksi pasca aborsi, 
sepsis sampai kematian. Dampak jangka panjang berupa mengganggu kesuburan sampai terjadinya infertilitas. Secara psikologis seks pra nikah memberikan dampak hilangnya harga diri, perasaan dihantui dosa, perasaan takut hamil, lemahnya ikatan kedua belah pihak yang menyebabkan kegagalan setelah menikah, serta penghinaan terhadap masyarakat.

b. HIV/AIDS

HIV berada terutama dalam cairan tubuh manusia. Cairan yang berpotensial mengandung virus HIV adalah darah, cairan sperma, cairan vagina dan air susu ibu. Sedangkan cairan yang tidak berpotensi untuk menularkan virus HIV adalah cairan keringat, airliur, air mata dan lain-lain. Bisa dilihat dari 2 gejala yaitu gejala Mayor (umum terjadi) dan gejala Minor (tidak umum terjadi):

GejalaMayor:

Berat badan menurun lebih dari 10\% dalam 1 bulan Diare kronis yang berlangsung lebih dari 1 bulan Demam berkepanjangan lebih dari 1 bulan

Penurunan kesadaran dan gangguan neurologisDemensia/ HIV ensefalopati

Gejala MInor:

Batuk menetap lebih dari 1 bulanDermatitis generalisata

Adanya herpes zostermultisegmental dan herpes zoster berulang Kandidias orofaringeal

Herpes simpleks kronis progresifLimfadenopati generalisata Infeksi jamur berulang pada alat kelamin wanitaRetinitis virus sitomegalo

c. Penyakit menular seksual

Penyakit menular seksual adalah penyakit yang menyerang manusia dan binatang melalui transmisi hubungan seksual, seks oral dan seks anal. Kata penyakit menular seksual semakin banyak digunakan, karena memiliki cakupan pada arti' orang yang mungkin terinfeksi, dan mungkin mengeinfeksi orang lain dengan tanda-tanda kemunculan penyakit. Penyakit menular seksual juga dapat ditularkan melalui jarum suntik dan juga kelahiran dan menyusui. Infeksi penyakit menular seksual telah diketahui selama ratusan tahun.

d. Narkoba

Narkotika adalah zat atau obat yang berasal dari tanaman atau bukan tanaman, baik sintetis maupun semi sintetis yang dapat menyebabkan penurunan atau perubahan kesadaran, hilangnya rasa nyeri dan dapat menimbulkan ketergantungan. (Kabin,2020) 
2. Dampak psikologis

Rasa bersalah, marah, sedih, sesal, malu, kesepian, tidak punya bantuan, bingung, stres, benci diri sendiri, benci orang yang terlibat, takut yang tidak jelas, insomnia, kehilangan konsentrasi, depresi, berduka, tidak punya pengharapan, cemas, tidak memaafkan diri sendiri, takut hukuman tuhan, mimpi buruk, merasa hampa, halusinasi.

\section{E. Faktor Penyebab terjadinya seks bebas dikalangan remaja}

Beberapa faktor yang mempengaruhi yaitu :

1. Kurangnya kasih sayang dari orang tua

Banyak para remaja yang terjerumus pada kenakalan remaja karena kurangnya ksih sayang dari orang tua mereka. Banyak orang tua yang terlalu memikirkan pekerjaan mereka dari pada memikirkan keadaan anak-anak mereka. Sehingga seorang anak merasakan tekanan psikologis pada diri mereka. Meraka tidak tahu harus berbagi cerita dengan siapa, sehingga saat ada maslah sering terjerumus dengan hasutan teman-teman mereka.(Pindawati,2018)

2. Kurangnya pengawasaan dari orang tua mereka

Sibuknya orang tua dengan pekerjaan membuat kurangnya pengawasan pada anak-anak mereka. Sehingga banyak anak-anak sering keluyuran dan bermainan dengan teman-teman mereka setelah pulang sekolah. Apalagi saat ini perkembangan teknologi semakin maju. Banyak anak-anak salah persepsi tentang penggunaan komputer maupun handpone dengan cara yang negatif. Misalnya : menonton gambar-gambar porno atau video porno yang ada. (Uly,2020)

3. Pergaulan dengan teman yang tidak sebaya

Usia remaja merupakn usia produktif dan sudah mulai mengenal yang namanya saling menyukai lawan jenis. Pergaulan yang salah bisa membuat mereka melakukan hal yang senonoh yang tidak seharusnya mereka lakukan. Misal : sehabis menonton video porno, mereka mempunyai hasrat hawa nafsu yang mendalam dan pengen melampiaskankepada lawan jenis mereka sehingga timbul perkosaan ataupun hubungan sexsual diluar nikah. Ada juga yang terjerumus dengan minum-minuman keras maupun sampai ke Narkoba. (Sulaiha,2018)

4. Tidak adanya bimbingan kepribadian yang baik

Sibuknya orang tua membuat kurangnya perhatian bagi seorang anak dan kurrang bimbingan yang baik. Banyak anak-anak yang menyalahgunakan kepercayaan orang tua mereka dan terjerumus pada kenakaln remaja. Kurangnya dasar-dasar agama juga membuat mereka melakukan tindakan yang negatif karena tidak tahunya pengetahuan agama dalam diri mereka 


\section{F. Cara remaja bersikap}

Hubungan seks di luar pernikahan menunjukkan tidak adanya rasa tanggung jawab dan memunculkan rentetan persoalan baru yang menyebabkan gangguan fisik dan psikososial manusia. Bahaya tindakan aborsi, menyebarnya penyakit menular seksual, rusaknya institusi pernikahan, serta ketidakjelasan garis keturunan.

Kehidupan keluarga yang diwarnai nilai sekuleristik dan kebebasan hanya akan merusak tatanan keluarga dan melahirkan generasi yang terjauh dari sendi-sendi agama.

Aktifitas seksual pada dasarnya adalah bagian dari naluri yang pemenuhannya sangat dipengaruhi stimulus dari luar tubuh manusia dan alam berfikirnya. Meminimalkan hal-hal yang merangsang, mengekang ledakan nafsu dan menguasainya. Masa remaja memang sangat memperhatikan masalah seksual. Banyak remaja yang menyukai bacaan porno, melihat film- film porno. Semakin bertambah jika mereka berhadapan dengan rangsangan seks seperti suara, pembicaran, tulisan, foto, sentuhan, dan lainnya. Hal ini akan mendorong remaja terjebak dengan kegiatan seks yang haram.

Perawatan organ reproduksi tidak identik dengan pemanfaatan tanpa kendali. Sistem organ reproduksi dalam pertumbuhannya sebagaimana organ lainnya, memerlukan masa tertentu yang berkesinambungan sehingga mencapai petumbuhan maksimal. Disinilah letak pentingnya pendampingan orang tua dan pendidik untuk memberi pemahaman yang benar tentang pertumbuhan organ reproduksi. Pemahaman remaja berkaitan dengan organ reproduksinya tentunya ditanamkan sesuai dengan kadar kemampuan logika dan umur mereka. Dengan demikian remaja tidak akan cemas ketika menghadapi peristiwa haid pertama, melewati masa premenstrual syndrome dengan aman, memahami hukum fiqh terkait dengan haid serta peristiwa lain yang mengiringi masa pubertas remaja.

Remaja juga harus bisa menjaga diri (isti'faaf). Hal ini mampu dilakukan pada remaja yang mempunyai kejelasan konsep hidup dalam menjalani hidupnya. Orang tua sejak usia dini harus menanamkan dasar yang kuat pada diri anak bahwa Alloh menciptakan manusia untuk beribadah kepada-Nya. Jika konsep hidup yang benar telah tertanam maka remaja akan memahamijati dirinya, menyadari akan tugas dan tanggung jawabnya, mengertihubungan dirinya dengan lingkungaanya. Kualitas akhlak akan terus terpupukdengan memahami batas-batas nilai, komitmen dengan tanggung jawab bersama dalam masyarakat. Remaja akan merasa damai di rumah yang terbangun dari keterbukaan, cinta kasih, saling memahami di antara sesama keluarga. Pengawasan dan bimbingan dari orang tua dan pendidik akan menghindarkan dari pergaulan bebas, komitmen terhadap aturan Allah baik dalam aurot (pakaian), pergaulan antar lawan jenis, menghindari ikhtilath dan sebagainya. 
JPM (Jurnal Perak Malahayati), Vol 3, No. 2. November 2021,

E:ISSN 2684-8899 (Online) P:ISSN 2685-547X (Cetak), Hal 142-150

\section{G. Pencegahan untuk menanggulangi seks bebas}

Bagi orang tua lebih memperhatikan pergaulan pada anaknya, tetapi tidak terlalu mengekang anak untuk bermain dengan teman sebayanya karena malah membuat psikologi seorang anak menjadi tertekan. Sebagian besar orangtua di jaman sekarang sangat sibuk mencari nafkah. Mereka sudah tidak mempunyai banyak kesempatan untuk dapat mengikuti terus kemana pun anak-anaknya pergi. Padahal, kenakalan remaja banyak bersumber dari pergaulan.

Oleh karena itu, orangtua hendaknya dapat memberikan inti pendidikan kepada para remaja. Inti pendidikan adalah sebuah pedoman dasar pergaulan yang singkat, padat, dan mudah di ingat secara mudah. Dengan memberikan inti pendidikan ini, kemana saja anak pergi ia akan selalu ingat pesan orangtua dan dapat menjaga dirinya sendiri. Anak menjadi mandiri dan dapat dipercaya, karena dirinya sendirinyalah yang akan mengendalikan dirinya sendiri. Selama seseorang masih memerlukan pihak lain untuk mengendalikan dirinya sendiri, selama itu pula ia akan berpotensi melanggar peraturan bila si pengendali tidak berada di dekatnya
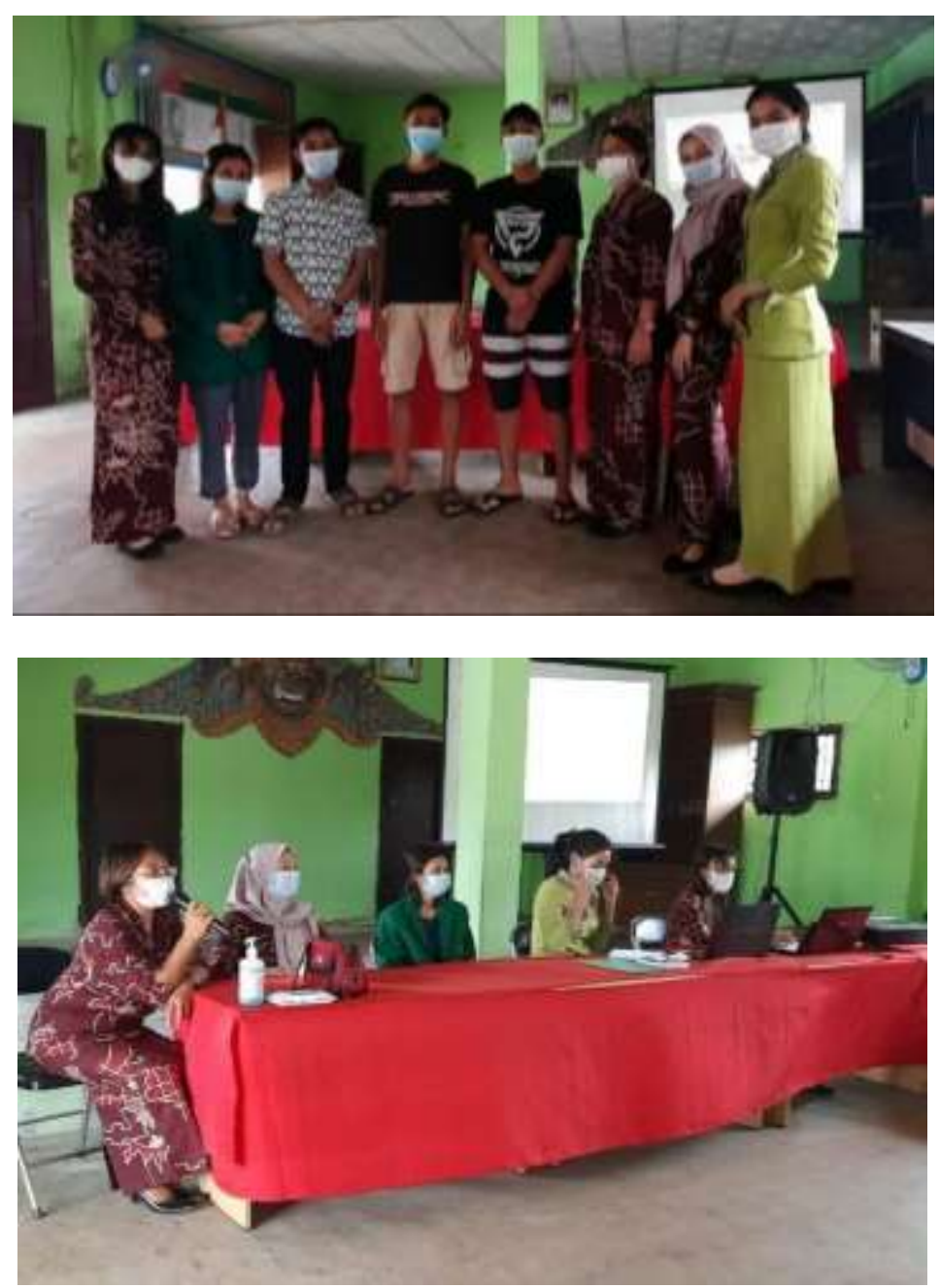


\section{KESIMPULAN}

Kesimpulan dari kegiatan penyuluhan penyuluhan tentang bahaya seks bebas pada remaja di desa rama murti III seputih raman lampung tengah tahun 2021 peserta mampu mengenali dampak perilaku seks bebas di kalangan remaja.

\section{DAFTAR PUSTAKA}

Arikunto, Suharsimi. 2002.Prosedur pengolahan SAP. Jakarta : PT Rhineka Cipta

Atfa, M. R. (2019). Pelaksanaan bimbingan dan konseling kesehatan reproduksi remaja dalam upaya penanggulangan perilaku seks bebas pada siswa Madrasah Aliyah Yayasan Taman Pendidikan Islamiyah (YATPI) Godong Grobogan (Doctoral dissertation, UIN Walisongo).

Ayu, G. F. (2019). KESEHATAN REPRODUKSI REMAJA DALAM MENYIAPKAN GENERASI EMAS BIMBINGAN DAN KONSELING. Edu Consilium: Jurnal Bimbingan dan Konseling Pendidikan Islam, 1(1), 13-22.

Jalilah, N. H., \& Prapitasari, R. (2021). KESEHATAN REPRODUKSI DAN KELUARGA BERENCANA. Penerbit Adab.

Kabain, H. A. (2020). Peran Keluarga, Guru, dan Sekolah Menyelamatkan Anak dari Pengaruh Napza. Alprin.

Lathifah, N. S., Isnaini, N., Yantina, Y., Retnowati, R., \& Yustiana, L. (2021). Konseling Kesehatan Reproduksi Meningkatkan Pengetahuan Tentang Kesuburan Dan Kesadaran Kesehatan Prakonsepsi. JURNAL PERAK MALAHAYATI, 3(1), 51-60.

PINDAWANTI, A. Y. (2018). STRATEGI MANAJEMEN KONFLIK ORANGTUA YANG SAMA-SAMA BEKERJA MENGHADAPI KENAKALAN REMAJA ANAKNYA (Doctoral dissertation, Universitas Airlangga).

Putri, R. D., \& Oktavika, A. T. (2021). PENYULUHAN TENTANG BAHAYA SEKS BEBAS PADA REMAJA DI DESA RAMA MURTI III SEPUTIH RAMAN LAMPUNG TENGAH TAHUN 2021. JURNAL PERAK MALAHAYATI, 3(1), 29-36.

Sulaiha, S., Us, K. A., \& Malik, A. (2021). UPAYA ORANG TUA DALAM MEMBINA AKHLAK REMAJA DI DESA TANAH TUMBUH KABUPATEN MUARO BUNGO (Doctoral dissertation, UIN Sulthan Thaha Saifuddin Jambi).

Uly, Z. H. (2020). PERAN ORANG TUA DALAM PENDIDIKAN AGAMA ISLAM ANAK KELUARGA PEDAGANG DI DESA CIKEMBULAN PEKUNCEN BANYUMAS (Doctoral dissertation, IAIN Purwokerto).

Utami, V. W., Iqmy, L. O., \& Fatimah, M. (2020). PENGABDIAN MASYARAKAT TENTANG BAHAYA SEKS BEBAS DI SMA NEGRI 15 BANDAR LAMPUNG. JURNAL PERAK MALAHAYATI, 2(1), 15-19. 